Gut, 13, 1972, 201-206

\title{
Serum bile acids in primary biliary cirrhosis
}

\author{
G. M. MURPHY, ALISON ROSS, AND BARBARA H. BILLING
}

From the Department of Medicine, Royal Free Hospital, London

SUMMARY Serum bile acid classes have been studied in 15 patients with primary biliary cirrhosis in five patients with cholestasis, and in five patients who had cirrhosis without cholestatic features. Conjugated monohydroxy bile acids (12-35\% serum total bile acids) were found in eight of 11 sera from patients with primary biliary cirrhosis, in sera from four patients with cholestasis but not in any of the five patients with cirrhosis. The glycine conjugates/taurine conjugates $(G / T)$ ratio in eight of 11 patients with primary biliary cirrhosis and two of four patients with cholestasis was $<1.0$.

Bile acid concentrations in seven patients with primary biliary cirrhosis were measured before and during cholestyramine therapy. Decreases in serum total bile acid concentrations were observed which were accompanied by small increases in the trihydroxy/dihydroxy ratio and also in the $G / T$ ratio in six of the seven patients. No association was found between the concentration of any particular conjugated or free bile acid and the presence or absence of pruritus.

The clinical syndrome of cholestasis has long been associated with disturbances of bile acid metabolism (Sherlock, 1966). Schaffner and Popper (1969) have suggested that cholestasis is related to the production of monohydroxy bile acids within the liver cell. There has, however, been no adequate study of serum monohydroxy bile acids both conjugated and free in patients with cholestasis to test this hypothesis. Since cholestasis is one of the features of primary biliary cirrhosis, individual serum bile acids have been determined in patients suffering from this condition as well as in patients with cholestasis due to other causes, and also in patients suffering from cirrhosis without cholestatic features.

It has been known for many years that pruritus in cholestatic liver disease is usually accompanied by raised serum bile acid levels (Carey, 1958) and that relief is associated with a reduction in serum bile acids (Carey and Williams, 1961; Van Itallie, Hashim, Crampton, and Tennent, 1961; Datta and Sherlock, 1963; Neale, Lewis, Weaver, and Panveliwalla, 1971). The degree of pruritus does not, however, appear to be directly related to the absolute level of total bile acids (Ross, Murphy, and Sherlock, 1970). In the present study the relationship between individual serum bile acid levels and pruritus has been examined to see if a particular bile acid could be responsible for the condition.

Received for publication 20 January 1972.

\section{Patients}

Twenty-five patients with liver disease were studied. Fifteen patients suffered from primary biliary cirrhosis; this diagnosis was made on clinical, serological, and histological grounds. Three of these patients were studied when in hepatic failure. In seven cases bile acid levels were measured both when the patient was not receiving cholestyramine and when cholestyramine had been administered for a minimum period of two weeks.

A further five patients who had biochemical features of cholestasis were grouped together: three had extrahepatic obstruction, one was recovering from chlorpromazine jaundice, and one patient had the clinical features of primary biliary cirrhosis but subsequent histological examination showed the diagnosis to be that of active chronic hepatitis. Only the patient with chlorpromazine jaundice received cholestyramine during the study.

The remaining five patients had cirrhosis without cholestatic features. The cirrhosis was of unknown aetiology in four cases and due to alcohol in one case.

None of the patients studied had features of bacterial overgrowth in the bowel. There was no evidence of intestinal diverticula and urinary indicans were normal. 


\section{Methods}

SERUM BILE ACID ESTIMATION

Serum obtained after an overnight fast was stored at $-15^{\circ} \mathrm{C}$ before analysis. Protein was precipitated from $1 \mathrm{ml}$ serum with ethanol and the supernatant solution evaporated to dryness. The residue was dissolved in $50 \%$ ethanol $(p \mathrm{H} \mathrm{10.0)}$ and the resulting solution extracted with ether/heptane $(1: 1, v / v)$. The bile acid classes in the ethanolic phase were obtained by silica gel thin-layer chromatography using ethylene dichloride/acetic acid/water $(1: 1: 0 \cdot 1)$ (Gregg, 1966). This system separates bile acid mixtures into their free, taurine, and glycine conjugated bile acid fractions and within these groups into tri-, di-, and monohydroxy bile acids. It does not separate either the conjugated or free forms of deoxycholic acid from those of chenodeoxycholic acid. The bile acid fractions were located with iodine, eluted from the silica gel with methanolic pyrophosphate buffer, and then estimated using an enzymatic fluorimetric procedure previously described for serum total bile acids (Murphy, Billing, and Baron, 1970). The determination of serum bile acids is described in greater detail elsewhere (Murphy, 1972).

The recovery of known amounts of aqueous solutions of bile acids added to serum before protein precipitation and carried through the entire procedure ranged from 70 to $87 \%$ (mean $77 \cdot 3 \pm$ SD 5.0). It was independent of the serum total bile acid concentration and the individual bile acid used. The standard solutions of lithocholic and taurolithocholic acids were prepared in $50 \%$ ethanol and under these conditions the recovery in each case was $91 \%$.

The precision of duplicate estimations on each sera was as follows: for serum concentrations of individual bile acids ranging from 2 to $15 \mu \mathrm{mol} / \mathrm{litre}$ the coefficient of variation was $12 \%$ and for concentrations greater than $15 \mu \mathrm{mol} / \mathrm{litre}$ it was $8 \%$. It was not possible to measure bile acid concentrations less than $2 \mu \mathrm{mol} /$ litre and such concentrations have been reported as not detected.

The specificity of the determination of serum bile acids using hydroxysteroid dehydrogenase is such that $3 \alpha$-bile acid sulphate esters (Palmer, 1967) are not estimated by this procedure.

Liver function tests performed included estimation of serum bilirubin (normal range $0 \cdot 3-1 \mathrm{mg} / 100 \mathrm{ml}$ ), alkaline phosphatase (normal range 3-13 KA units/ $100 \mathrm{ml}$ ), and total cholesterol (normal range 170-260 $\mathrm{mg} / 100 \mathrm{ml}$ ).

\section{Results}

The levels of serum individual bile acids found in primary biliary cirrhosis are shown in Table $I$ and those in other liver diseases in Table II together with details of cholestyramine treatment and liver function tests.

\section{SERUM BILE ACIDS IN PATIENTS NOT RECEIVING CHOLESTYRAMINE THERAPY}

\section{Total bile acids}

The total bile acids were elevated in all the sera examined (normal value $<8 \mu \mathrm{mol} /$ litre; Murphy et al, 1970). The mean value $(197 \cdot 3 \pm 90 \mu \mathrm{mol} / \mathrm{litre})$ found in the sera of the group with primary biliary cirrhosis was statistically higher $(\mathrm{P}<0.001)$ than that of the cirrhotic group (43.5 $\pm 26.4 \mu \mathrm{mol} /$ litre) but was not different from that found in patients

\begin{tabular}{|c|c|c|c|c|c|c|c|c|c|c|}
\hline \multirow[t]{2}{*}{ Diagnosis } & \multicolumn{10}{|c|}{ Patient No. } \\
\hline & 1 & 1 & $I^{1}$ & 2 & 2 & 3 & 4 & 5 & 6 & 6 \\
\hline Pruritus & + & - & - & + & - & + & - & - & + & _- \\
\hline Cholestyramine & Off & On & On & Off & On & On & Off & On & Off & On \\
\hline \multicolumn{11}{|l|}{ Bile Acids ( $\mu \mathrm{mol} / \mathrm{litre})$} \\
\hline Total & 166 & 86 & 146 & 171 & 38 & 35 & 102 & 30 & 154 & 74 \\
\hline Taurotrihydroxy & 12 & 6 & 33 & 20 & 9 & 15 & 44 & ND & 32 & 29 \\
\hline Taurodihydroxy & 46 & 19 & 12 & 69 & 9 & 10 & 8 & 11 & 35 & 9 \\
\hline Tauromonohydroxy & 31 & 19 & ND & ND & ND & ND & ND & ND & 23 & ND \\
\hline Glycotrihydroxy & 36 & 20 & 55 & 12 & ND & 5 & 7 & 10 & 33 & 15 \\
\hline Glycodihydroxy & 41 & 23 & 46 & 70 & 20 & 5 & 43 & 9 & 14 & 14 \\
\hline Glycomonohydroxy & ND & ND & ND & ND & ND & ND & ND & ND & 17 & 7 \\
\hline \multicolumn{11}{|l|}{ Ratio } \\
\hline Glycine/Taurine & 0.87 & 0.98 & $2 \cdot 24$ & 0.92 & $1 \cdot 11$ & 0.40 & 0.96 & 1.73 & 0.71 & 0.95 \\
\hline Trihydroxy/dihydroxy & 0.55 & 0.62 & 1.52 & 0.23 & 0.31 & 1.33 & 1.00 & 0.50 & 1.32 & 1.91 \\
\hline Cholesterol (mg/100 ml) & 280 & 340 & 270 & 240 & 210 & 220 & 265 & 320 & 460 & 420 \\
\hline Total bilirubin $(\mathrm{mg} / 100 \mathrm{ml})$ & $2 \cdot 5$ & $2 \cdot 5$ & $12 \cdot 0$ & $1 \cdot 4$ & $1 \cdot 0$ & $<0.5$ & $<0.5$ & $2 \cdot 5$ & $8 \cdot 5$ & $6 \cdot 0$ \\
\hline
\end{tabular}

Table I Results of bile acid estimations in cases of primary biliary cirrhosis 
with other cholestatic liver diseases $(115 \pm 68$ $\mu \mathrm{mol} /$ litre).

Free bile acids

Unconjugated bile acids were not detected in any of the sera examined.

\section{Monohydroxy bile acids}

In eight of 11 sera from patients with primary biliary cirrhosis and in sera from four patients with cholestasis, spots were detected with $\mathbf{R}_{\mathbf{f}}$ values corresponding to those of taurolithocholic and glycolithocholic acids. Subsequent tests have confirmed that such spots were monohydroxy bile acids but because of the small absolute amounts present it was not possible to establish their identity. They do not, however, appear to be conjugates of lithocholic acid (Murphy, Jansen, and Billing, 1971) and consequently such compounds have been reported as taurine or glycine conjugated monohydroxy bile acids.

In the eight biliary cirrhotic patients 18 to $35 \%$ of the total bile acids were present as monohydroxy bile acids, while in the four patients with cholestasis values ranged from 12 to $28 \%$. Monohydroxy bile acids were not detected in any of the sera from patients with non-cholestatic liver disease (Fig. 1). The amounts of monohydroxy bile acid present did not correlate with the serum total bile acid levels although the highest percentage values were found to be associated with highest total bile acid concentrations.

\section{Hydroxylation patterns}

The raised concentrations of total bile acids were the result of increases in both total trihydroxy and total

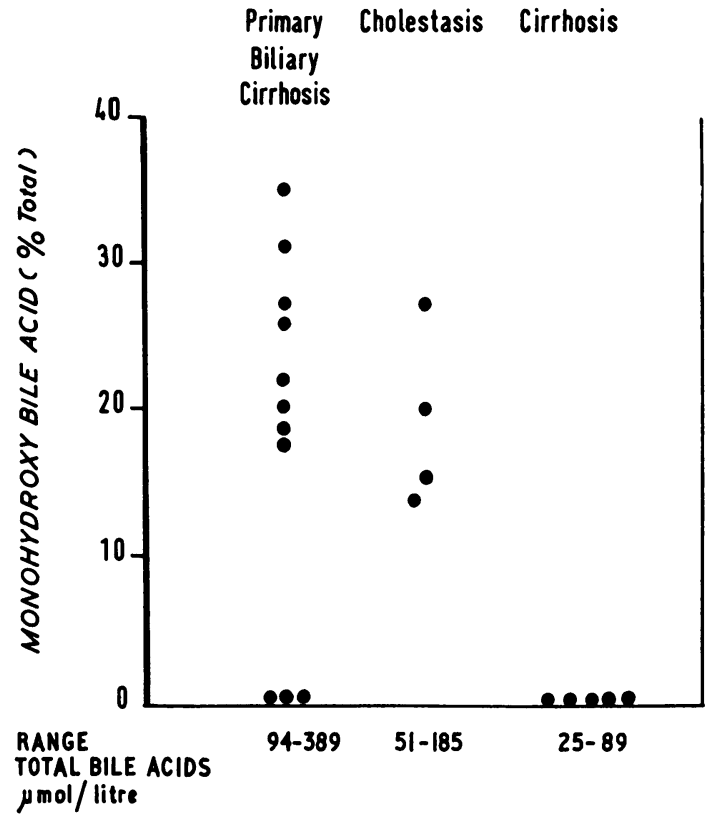

Fig. 1 Serum monohydroxy bile acids (expressed as a percentage of serum total bile acids) in patients with primary biliary cirrhosis, cholestasis, and cirrhosis.

dihydroxy fractions of all sera examined. The lowest values of the ratio of the total trihydroxy: total dihydroxy bile acids (TRI/DI ratio) were found in the primary biliary cirrhotic group. There was, however, considerable overlap in the value of this ratio in the three groups of patients. No correlation was found

\begin{tabular}{|c|c|c|c|c|c|c|c|c|c|c|c|c|c|}
\hline 7 & 7 & $7^{1}$ & 8 & 8 & 9 & 10 & 11 & 12 & 13 & 13 & 14 & 14 & $15^{1}$ \\
\hline$\stackrel{+}{\text { Off }}$ & $\overline{\text { On }}$ & $\overline{\text { On }}$ & $\stackrel{+}{\text { Off }}$ & $\bar{O} \mathbf{n}$ & $\bar{O}$ & $\stackrel{+}{\text { On }}$ & $\overline{\text { Off }}$ & $\stackrel{+}{\text { Off }}$ & $\stackrel{+}{\text { Off }}$ & $\stackrel{+}{\text { On }}$ & $\stackrel{+}{\text { Off }}$ & $\overline{\text { On }}$ & $\overline{\text { Off }}$ \\
\hline $\begin{array}{r}389 \\
120 \\
76 \\
32 \\
61 \\
57 \\
43\end{array}$ & $\begin{array}{r}367 \\
31 \\
88 \\
44 \\
119 \\
85 \\
\text { ND }\end{array}$ & $\begin{array}{r}301 \\
19 \\
52 \\
19 \\
107 \\
96 \\
8\end{array}$ & $\begin{array}{r}322 \\
34 \\
68 \\
57 \\
34 \\
74 \\
55\end{array}$ & $\begin{array}{r}179 \\
7 \\
49 \\
\text { ND } \\
49 \\
49 \\
25\end{array}$ & $\begin{array}{r}128 \\
54 \\
5 \\
5 \\
24 \\
29 \\
11\end{array}$ & $\begin{array}{r}110 \\
11 \\
35 \\
6 \\
29 \\
18 \\
11\end{array}$ & $\begin{array}{r}224 \\
23 \\
88 \\
\text { ND } \\
93 \\
20 \\
\text { ND }\end{array}$ & $\begin{array}{r}91 \\
10 \\
27 \\
16 \\
26 \\
12 \\
\text { ND }\end{array}$ & $\begin{array}{r}190 \\
26 \\
46 \\
26 \\
13 \\
46 \\
33\end{array}$ & $\begin{array}{l}96 \\
23 \\
16 \\
12 \\
17 \\
14 \\
14\end{array}$ & $\begin{array}{r}141 \\
6 \\
39 \\
31 \\
33 \\
25 \\
7\end{array}$ & $\begin{array}{r}75 \\
4 \\
23 \\
9 \\
21 \\
12 \\
6\end{array}$ & $\begin{array}{r}220 \\
37 \\
29 \\
17 \\
40 \\
65 \\
32\end{array}$ \\
\hline $\begin{array}{l}0.71 \\
1.36 \\
52\end{array}$ & $\begin{array}{l}1.25 \\
0.90 \\
76\end{array}$ & $\begin{array}{l}2 \cdot 34 \\
0 \cdot 85 \\
80\end{array}$ & $\begin{array}{l}1.03 \\
0.48 \\
50\end{array}$ & $\begin{array}{r}2.19 \\
0.57 \\
51\end{array}$ & $\begin{array}{l}1 \cdot 00 \\
2 \cdot 29 \\
49\end{array}$ & $\begin{array}{l}1 \cdot 12 \\
0 \cdot 75 \\
7\end{array}$ & $\begin{array}{r}1.02 \\
1.07 \\
184\end{array}$ & $\begin{array}{l}0.72 \\
0.93 \\
62\end{array}$ & $\begin{array}{l}0.94 \\
0.43 \\
35\end{array}$ & $\begin{array}{l}0.88 \\
1 \cdot 33 \\
31\end{array}$ & $\begin{array}{l}0.86 \\
0.61 \\
84\end{array}$ & $\begin{array}{l}1.08 \\
0.72 \\
52\end{array}$ & $\begin{array}{l}1.65 \\
0.82 \\
45\end{array}$ \\
\hline $\begin{array}{l}400 \\
16.0\end{array}$ & $\begin{array}{l}240 \\
16 \cdot 0\end{array}$ & $\begin{array}{l}140 \\
27 \cdot 0\end{array}$ & $\begin{array}{r}360 \\
4 \cdot 5\end{array}$ & $\begin{array}{r}340 \\
7 \cdot 5\end{array}$ & $\begin{array}{l}270 \\
13.6\end{array}$ & $\begin{array}{r}615 \\
8 \cdot 0\end{array}$ & $\begin{array}{r}740 \\
15 \cdot 0\end{array}$ & $\begin{array}{r}140 \\
6 \cdot 1\end{array}$ & $\begin{array}{r}370 \\
8 \cdot 8\end{array}$ & $\begin{array}{r}345 \\
9.6\end{array}$ & $\begin{array}{r}390 \\
8 \cdot 8\end{array}$ & $\begin{array}{r}300 \\
8 \cdot 0\end{array}$ & $\begin{array}{l}465 \\
9.0\end{array}$ \\
\hline
\end{tabular}

Table I-Continued

${ }^{1}$ Indicates terminal specimen. ND indicates not detected. 


\begin{tabular}{|c|c|c|c|c|c|c|c|c|c|c|}
\hline \multirow[t]{3}{*}{ Diagnosis } & \multicolumn{10}{|c|}{ Patient No. } \\
\hline & \multicolumn{3}{|c|}{ Extrahepatic Obstruction } & \multirow{2}{*}{$\begin{array}{l}\begin{array}{l}\text { Drug } \\
\text { Jaundice }\end{array} \\
19\end{array}$} & \multirow{2}{*}{$\begin{array}{l}\begin{array}{l}\text { Active } \\
\text { Chronic } \\
\text { Hepatitis }\end{array} \\
20\end{array}$} & \multicolumn{5}{|l|}{ Cirrhosis } \\
\hline & 16 & 17 & 18 & & & 21 & 22 & 23 & 24 & 25 \\
\hline Pruritus & + & + & - & + & - & _- & - & _- & - & _- \\
\hline Cholestyramine & Off & Off & Off & On & Off & Off & Off & Off & Off & Off \\
\hline \multicolumn{11}{|l|}{ Bile Acids ( $\mu \mathrm{mol} /$ litre) } \\
\hline Total & 161 & 51 & 63 & 153 & 185 & 24 & 89 & 35 & 26 & 44 \\
\hline Taurotrihydroxy & 27 & 7 & 3 & 37 & 10 & 7 & 14 & 9 & ND & 4 \\
\hline Taurodihydroxy & 33 & 12 & 18 & 63 & 58 & 3 & 18 & 8 & 9 & 16 \\
\hline Tauromonohydroxy & 32 & 9 & 9 & 24 & 18 & ND & ND & ND & ND & ND \\
\hline Glycotrihydroxy & 56 & 6 & 19 & 9 & 56 & 8 & 13 & 15 & 8 & 12 \\
\hline Glycodihydroxy & 13 & 12 & 14 & 9 & 35 & 6 & 44 & 3 & 9 & 12 \\
\hline Glycomonohydroxy & ND & 5 & ND & 11 & 8 & ND & ND & ND & ND & ND \\
\hline \multicolumn{11}{|l|}{ Ratio: } \\
\hline Glycine/Taurine & 0.75 & 0.82 & $1 \cdot 10$ & 0.23 & $1 \cdot 15$ & 1.40 & 1.71 & 1.06 & 1.88 & 1.20 \\
\hline Trihydroxy/dihydroxy & 1.80 & 0.54 & 0.69 & 0.64 & 0.71 & 1.07 & 0.44 & $2 \cdot 18$ & 0.44 & 0.57 \\
\hline $\begin{array}{l}\text { Alkaline phosphatase } \\
\text { (KA units } / 100 \mathrm{ml} \text { ) }\end{array}$ & 140 & 104 & 142 & 45 & 55 & 7 & 9 & 9 & 22 & 24 \\
\hline Cholesterol $(\mathrm{mg} / 100 \mathrm{ml})$ & 630 & 260 & 345 & 200 & 950 & 210 & 180 & 200 & 230 & 210 \\
\hline Total bilirubin $(\mathrm{mg} / 100 \mathrm{ml})$ & $12 \cdot 2$ & $2 \cdot 8$ & $18 \cdot 4$ & 0.8 & $6 \cdot 0$ & $<0.5$ & $<0.5$ & $<0.5$ & $<0.5$ & $<0.5$ \\
\hline
\end{tabular}

Table II Results of bile acid estimations in extrahepatic obstruction, drug jaundice, active chronic hepatitis, and cirrhosis

between the TRI/DI ratio and the corresponding total bile acid concentration in any of the groups.

\section{Conjugation patterns}

The values for the ratio of total glycine/total taurine conjugates $(\mathrm{G} / \mathrm{T})$ are shown in Tables I and II. In eight of 11 patients with primary biliary cirrhosis and two of four patients with cholestasis the $G / T$ ratio was $<1.0$ whereas the values of this ratio found in the sera of patients without cholestasis ranged from 1.06 to 1.88 .

No significant correlation was found between the value of the $G / T$ ratio and the corresponding total bile acid concentration in any of the groups. Nor was there any significant correlation between the TRI/ $D I$ ratio and the $G / T$ ratio. Only one patient (case 15) had a $G / T$ ratio $>1.2$ and also had serum monohydroxy bile acids. There was, however, no significant correlation between $\mathrm{G} / \mathrm{T}$ ratio and the absolute or relative amounts of monohydroxy bile acids present.

Bile acid concentration and other liver function tests No correlation was found between the concentration of serum total bile acids or any specific bile acid fraction and either serum alkaline phosphatase, serum cholesterol concentration, or serum bilirubin.

SERUM BILE ACIDS AND PRURITUS

The results of bile acid estimations made before and during cholestyramine therapy are given in Table I. Serum total bile acids fell in each of the seven patients (cases 1, 2, 6, 7, 8, 13, and 14). This fall was not always associated with relief from pruritus (case 13) and a high level of serum total bile acids was not necessarily accompanied by pruritus (cases $4,15,20$, and 22).

No association was found between the concentration of any particular bile acid and the presence or absence of pruritus.

The fall in serum total bile acids as a result of cholestyramine therapy was accompanied by small increases in the TRI/DI ratio and also in the $G / T$ ratio in six of the seven patients studied.

There was a significant difference $(P<0.001)$ between the $G / T$ ratios of sera taken from patients with pruritus (mean $0.78 \pm 0.05$ ) and sera taken when pruritus was absent (mean 1.39 $\pm 0 \cdot 2$ ) (Fig. 2). Pruritus was found to be associated with low G/T ratios even when the patients were receiving cholestyramine therapy (cases 3, 13, and 19). Relief from pruritus was not experienced in patient no. 13 who was the only patient who did not show an increase in $\mathrm{G} / \mathrm{T}$ ratio when on treatment.

\section{Terminal cases}

The three patients studied when in liver cell failure did not complain of pruritus although their serum bile acid levels remained high (cases $1^{1}, 7^{1}$, and $1^{1}$ in Table I). All three had relatively high $\mathrm{G} / \mathrm{T}$ ratios including case 15 who was not receiving cholestyramine.

\section{Discussion}

As indicated in Fig. 1 levels of conjugated monohydroxy bile acids as high as $35 \%(15-112 \mu \mathrm{mol} /$ 


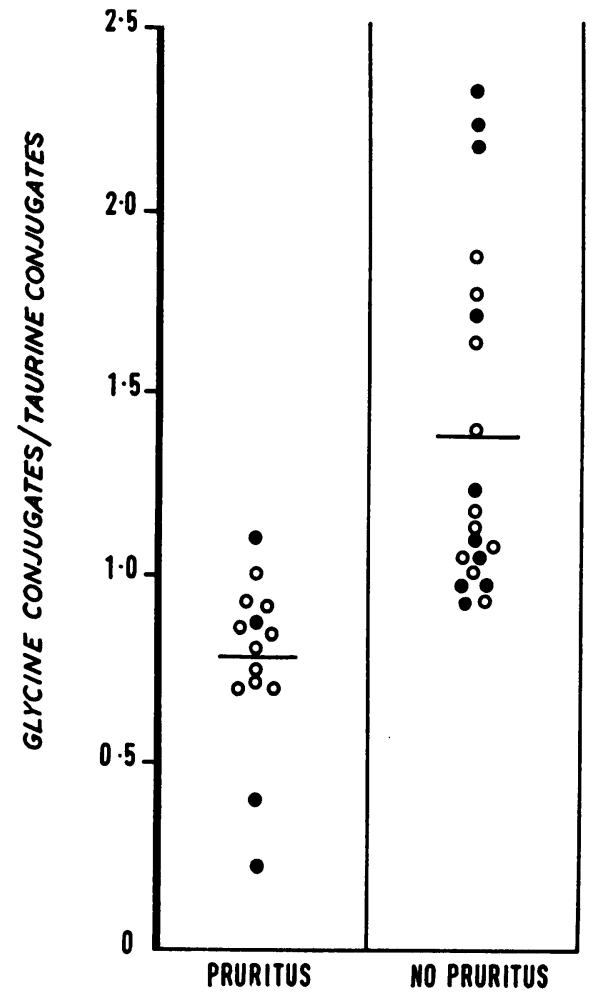

Fig. 2 Ratio of glycine conjugated bile acids to taurine conjugated bile acids from patients with and without pruritus. Bar indicates mean value. Patients receiving cholestyramine, $\bigcirc$ Patients not receiving cholestyramine

litre) of the total serum bile acids have been found in the serum of patients with primary biliary cirrhosis.

Failure to detect monohydroxy bile acids by previous investigators may be related to the type of assay used. Many modern methods of bile acid estimation employ gas liquid chromatography procedures for which it is essential that conjugates are hydrolysed and derivatives prepared. With respect to monohydroxy bile acids such methods have been criticized on two counts. First, conjugates of lithocholic acid are particularly resistant to hydrolysis and hence quantitative recoveries are difficult to obtain (Carey and Williams, 1965). Secondly, lithocholic acids and other relatively nonpolar bile acids, if present, may be lost if the customary alumina column procedure is not modified (Okishio and Nair, 1966; Ali and Javitt, 1970). The method used for the present study employed a simple extraction procedure followed by enzymatic analysis and thus allowed bile acids of widely divergent polarities to be quantitatively assayed (Murphy, 1972).
The origin of the high levels of serum monohydroxy bile acids found in the present study remains obscure. If such bile acids were the result of $7 \alpha-$ dehydroxylation of primary bile acids in the intestinal tract then one might expect to find high serum levels associated with increased amounts of lithocholic acid in intestinal contents. A study by Portella, Ross, and Sherlock (1972) has reported relatively large amounts of conjugated monohydroxy bile acids present in duodenal fluid from patients with primary biliary cirrhosis. Mass spectral analysis of derivatives of the monohydroxy bile acid fraction in bile from one such patient demonstrated that the only monohydroxy bile acid present was lithocholic acid. However, a similar examination of the monohydroxy bile acid fraction present in serum pooled from five patients with primary biliary cirrhosis indicated that the compound under investigation was not lithocholic acid but an unsaturated monohydroxy bile acid (Murphy et al, 1971). This preliminary evidence suggests that the serum monohydroxy bile acids found in the present study may be the result of primary biosynthesis in the liver, and that they are not readily excreted in the bile.

In a study of bile acids in urine from infants with biliary atresia, Makino, Sjovall, Norman, and Strandvik (1971) have reported the presence of significant amounts of a similar unsaturated monohydroxy bile acid ( $3 \beta$-hydroxy-5-cholenoic acid). The occurrence of such unsaturated compounds may be evidence of a biosynthetic pathway for bile acids such as that described in an in vitro study by Mitropoulos and Myant (1967) and in an in vivo study by Anderson, Ali, Kok, and Javitt (1971). The fact that only one of the five patients with serum bilirubin levels less than $3 \mathrm{mg} / 100 \mathrm{ml}$ had monohydroxy bile acids present in serum (case 1) suggests that these acids are not a cause of cholestasis but a consequence of it.

The values of the TRI/DI ratio found in this study are similar to those of Neale et al (1971). The taurotrihydroxy/taurodihydroxy ratio was often quite different from the corresponding glycotrihydroxy/glycodihydroxy ratio even in patients not receiving cholestyramine therapy. Similar differences have been reported by Panveliwalla, Tabaqchali, Lewis, and Wootton (1970) in the serum of normal subjects and by Neale et al (1971) in the serum of patients with liver disease.

The finding of low $\mathrm{G} / \mathrm{T}$ ratios in cholestatic liver disease is in accord with the results of Neale et al (1971). The levels found in the patients with noncholestatic cirrhosis are somewhat higher (range 1.06-1.88) but there is considerable overlap between the groups.

Since the relief from pruritus which accompanies 
cholestyramine therapy is generally associated with a fall in serum total bile acids, it might be anticipated that a particular bile acid is responsible for this association (Ross et al, 1970). However, no positive association between any particular individual bile acid fraction and the presence or absence of pruritus could be demonstrated. The G/T ratio does appear to have some significance in that the mean level $(0.78 \pm 0.23)$ found when pruritus was present was significantly different $(P<0.001)$ from that found when pruritus was absent (1.39 \pm 0.45$)$ (Fig. 2). This is also in accord with the results of Neale et al (1971), who found an increase in the proportion of glycine to taurine conjugates in two of their three cases after treatment. Kenny and Garbutt (1970) have demonstrated in normal subjects that the major alteration of bile acid metabolism by cholestyramine administration was enhanced hepatic synthesis of glycocholic acid. However, studies in vitro (Hagerman, Cook, and Schneider, 1971) have demonstrated that cholestyramine has a greater affinity for taurineconjugated than glycine-conjugated bile acids. Three of the highest values for the $G / T$ ratio in the present study were found in serum from patients in hepatic failure (cases $1^{1}, 7^{1}, 1^{1}$ in Table I). Two of these patients had been taking cholestyramine for longer than two years. This suggests that the increase in $G / T$ ratio observed in the present study is a consequence of cholestyramine selectivity rather than an indication of improved liver function. It may be that the association observed between pruritus and bile acids is a reflection of amino acid distribution rather than a direct consequence of bile acid metabolism.

We would like to thank Professor S. Sherlock for permission to study patients under her care, and Professor D. N. Baron and the Chemical Pathology Department for giving results of liver function tests.

This work was supported by a grant from the Medical Research Council.

References

Ali, S. S., and Javitt, N. B. (1970). Quantitative estimation of bile salts in serum. Canad. J. Biochem., 48, 1054-1057.
Anderson, K., Ali, S. S., Kok, E., and Javitt, N. B. (1971). Bile acid synthesis in human liver. Clin. Res., 19, 386.

Carey, J. B., Jr. (1958). The serum trihydroxy-dihydroxy bile acid ratio in liver and biliary tract disease. J. clin. Invest., 37, 14941503.

Carey, J. B.. Jr., and Williams, G. (1961). Relief of pruritus of jaundice with a bile acid sequestering resin. J. Amer. med. Ass., 176, 432-435.

Carey, J. B., Jr., and Williams, G. (1965). Lithocholic acid in human blood serum. Science, 150, 621-622.

Datta, D. V., and Sherlock, S. (1963). Treatment of pruritus of obstructive jaundice with cholestyramine. Brit. med. J., 1, 216219.

Gregg, J. A. (1966). New solvent systems for thin-layer chromatography of bile acids. J. Lipid Res., 7, 579-581.

Hagerman, L. M., Cook, D. A., and Schneider, D. L. (1971). In vitro binding of taurine- and glycine-conjugated bile salts by cholestyramine. Fed. Proc. (Abstr.) 30, 344.

Kenny, T. J., and Garbutt, J. T. (1970). Effect of cholestyramine on bile acid metabolism in normal man. (Abstr.) Gastroenterology, $58,966$.

Makino, I., Sjovall, J., Norman, A., and Strandvik, B. (1971). Excretion of $3 \beta$-hydroxy-5-cholenoic and $3 a$-hydroxy-5a-cholanoic acids in urine of infants with biliary atresia. Febs Letters, 15, 161-164.

Mitropoulos, K. A., and Myant, N. B. (1967). The formation of lithocholic acid, chenodeoxycholic acid and alpha- and beta muricholic acids from cholesterol incubated with rat-liver mitochondria. Biochem. J., 103, 472-479.

Murphy, G. M. (1972). Ann. clin. Biochem., 9, in press.

Murphy, G. M., Billing, Barbara H., and Baron, D. N. (1970). A fluorimetric and enzymatic method for the estimation of serum total bile acids. J. clin. Path., 23, 594-598.

Murphy, G. M., Jansen, F. H., and Billing, Barbara, H. (1971). An abnormal bile salt in primary biliary cirrhosis. Gut, 12, 771 .

Neale, G., Lewis, B., Weaver, V., and Panveliwalla, D. (1971). Serum bile acids in liver disease. Gut, 12, 145-152.

Okishio, T., and Nair, P. P. (1966). Studies on bile acids. Some observations on the intracellular localisation of major bile acids in rat liver. Biochemistry, 5, 3662-3668.

Palmer, R. H. (1967). The formation of bile acid sulphates: A new pathway of bile acid metabolism in humans. Proc. nat. Acad. Sci., 58, 1047-1050.

Panveliwalla, D., Tabaqchali, S., Lewis, B., and Wootton, I. D. P. (1970). Determination of individual bile acids in biological fluids by thin-layer chromatography and fluorimetry. J. clin. Path., 23, 309-314.

Portella, F. W., Ross, A., and Sherlock, S. (1972). Biliary bile salts in cholestatic liver disease. In preparation.

Ross, A., Murphy, G. M., and Sherlock, S. (1970). The effect of a new cholestyramine preparation on blood bile salt levels and pruritus in patients with liver disease. In Proceedings of 4th World Congress of Gastroenterology, Copenhagen, 1970.

Schaffiner, F., and Popper, H. (1969). Hypothesis: cholestasis is the result of hypoactive hypertrophic smooth endoplasmic recticulum in the hepatocyte. Lancet, 2, 355-359.

Sherlock, S. (1966). Biliary secretory failure in man. The problems of cholestasis. Ann. intern. Med., 65, 397-408.

Van Itallie, T. B., Hashim, S. A., Crampton, R. S., and Tennent, D. M. (1961). The treatment of pruritus and hypercholesterolaemia of primary biliary cirrhosis with cholestyramine. New Engl. J. Med., 265, 469-474. 